\title{
Esterification of rosin with methyl alcohol for fuel applications
}

\author{
Esterificación de colofonia para aplicaciones como combustible
}

\author{
Duban F. García (iD ${ }^{1 *}$, Felipe Bustamante (D) ${ }^{1}$, Aída Luz Villa (D) ', Edwin A. Alarcón \\ ${ }^{1}$ Departamento de Ingeniería Química, Facultad de Ingeniería, Universidad de Antioquia. Calle 70 \# 52-21. C. P. 050010. \\ Medellín, Colombia.
}

\section{CITE THIS ARTICLE AS:}

D. F. García, F. Bustamante, A.

L. Villa, and E. A. Alarcón.

"Esterification of rosin with methyl alcohol for fuel applications", Revista Facultad de Ingeniería Universidad de Antioquia, no. 100, pp. 10-20, Jul-Sep 2021. [Online].

Available: https :

//www.doi.org/10.17533/

udea.redin. 20201214

\section{ARTICLE INFO:}

Received: April 17, 2020

Accepted: December 07, 2020

Available online: December

09, 2020

\section{KEYWORDS:}

Hydrocarbons; acidity; chromatographic analysis; materials science; calcium

Hidrocarburos; acidez; análisis cromatográfico; ciencia de los materiales; calcio
ABSTRACT: Oleoresin is obtained via tapping of pine trees and as a by-product of Kraft process in the pulp industry. Because of its low production cost, it is an attractive source for biofuels. Oleoresin is composed mainly of rosin laround $80 \%$, a solid mixture of isomeric abietic acids), and it cannot be used directly as fuel in engines. However, the methyl ester of rosin has lower boiling and melting points than rosin, and it is highly soluble in hydrocarbons. Esterification of rosin with methyl alcohol was evaluated over acid and basic heterogeneous catalysts in the presence of several solvents. In contrast to acid catalysts, basic materials were active in the reaction. In particular, a low-cost calcium-based material showed the best performance. A 55\% conversion of rosin with complete selectivity to methyl esters was obtained with $40 \%$ wt. loading of the calcium-based material (respect to rosin), under mild conditions (atmospheric pressure, $64^{\circ} \mathrm{C}$ and $3.5 \mathrm{hl}$ and without solvent. Other catalysts, such as magnesium oxide, titanium dioxide, and alumina, achieved up to $30 \%$ conversion. Calcium carbonate and calcium hydroxide were the main phases in the calcium-based material, suggesting that the strength of basic sites can be an important property of the catalyst activity. A calcium-based material was used in five reaction cycles, obtaining a significant reduction in the activity attributed to the leaching of some phases of the catalyst.

RESUMEN: La oleorresina es obtenida mediante la extracción de los árboles de pino o como un subproducto del proceso Kraft para la obtención de papel. Su bajo costo de producción la convierte en un buen candidato para ser materia prima en la obtención de biocombustibles. La oleorresina está compuesta por colofonia lalrededor del $80 \%$, que es una mezcla de isómeros del ácido abiéticol, la cual no puede usarse directamente en motores de combustión. Por su parte, los ésteres de colofonia poseen menor temperatura de ebullición y fusión, además de alta solubilidad en hidrocarburos. La metil-esterificación de colofonia fue evaluada sobre catalizadores ácidos y básicos, y en presencia de varios solventes. A diferencia de los catalizadores ácidos, los básicos mostraron actividad en la reacción. Particularmente, un material cálcico de bajo costo mostró el mejor desempeño con una conversión de $55 \%$ y selectividad completa hacia los metil-ésteres cargado a $40 \%$ en peso respecto a la colofonia, a condiciones suaves de reacción (presión atmosférica, $64^{\circ} \mathrm{C}$ y 3,5 horas) y sin presencia de solvente. Se encontró que las fases principales del material cálcico fueron el carbonato e hidróxido de calcio, sugiriendo que la fuerza de los sitios básicos juega un papel importante en la reacción. Este material cálcico fue usado en cinco ciclos de reacción, obteniendo una reducción significativa de su actividad en la reacción, atribuida a una posible lixiviación de algunas fases del catalizador.

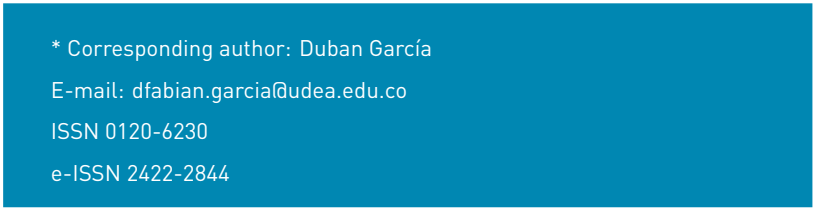

\section{Introduction}

Oleoresin is an organic complex mixture mainly composed of rosin and turpentine. The main processes to obtain 
oleoresin are via exudation of pine trees and as a byproduct of the pulp industry. Rosin is a solid mixture of isomeric abietic acids, reaching a content of around $80 \%$ of oleoresin [1]. Due to the low production cost of oleoresin and the high content of rosin in oleoresin, rosin can be considered as an attractive source for biofuels; however, its direct use as fuel in spark and compression ignition engines is not possible (i.e., it is a solid) and a previous transformation is required. The main transformations of rosin reported in the literature aimed at its use as fuel are focused on reducing the heavy molecular weight and removing the acid group from resin acids (i.e., thermal and catalytic cracking, and decarboxylation) [2-5]. Usually, these transformations are performed sequentially, starting with decarboxylation, or simultaneously (one-pot reactions), demanding high energy consumption, which causes a dramatic increase in the fuel production cost.

Other transformations at mild conditions, such as reduction and esterification, are desirable from the environmental and economic standpoints. However, in a previous work, we reported the drawbacks of using rosin methyl esters as a fuel component li.e., at high contents), mainly due to the high propensity of the methyl esterification product of rosin to remain as a solid [6]. Nevertheless, an application of methyl esters of rosin as a fuel additive (i.e., concentration lower than 1,000 ppm, in which it can be completely solubilized in hydrocarbons, as shown for rosin-derived compounds blended with a-olefin [7]), has been scarcely reported.

The methyl ester of rosin, also called methyl rosinate (CAS 68186-14-1), can be produced by esterification of rosin with methyl alcohol, and it is commercially available with trade names such as abalyn or abalyn D-E. The distribution of esterification products depends on the rosin composition, which, in turn, is related to its source li.e., gum rosin, wood rosin, and tall oil rosin). Rosin is mainly composed of resin acids, namely, abietic, dehydroabietic, neoabietic, palustric, pimaric, isopimaric, and levopimaric acids [1]; these compounds are readily esterified by methylation yielding products with interesting properties. In particular, methyl abietate (CAS 127-25-3) displays similar uses to methyl rosinate, including plasticizer, and solvent for vinyls and cellulosic materials [8-11].

The use of homogeneous catalysts has been reported for different esterification reactions leading to high ester yields (e.g., $>90 \%$ of conversion of nopol into nopyl acetate has been reported with sulfuric acid as a catalyst [12]). This kind of catalyst is typically used in the esterification of rosin and resin acids with different alcohols, particularly, Lewis and Brønsted acids, such as acetic acid, sulfuric acid, and p-toluenesulfonic acid. For instance, the esterification of abietic and dehydroabietic acids in the presence of sulfuric acid as a catalyst displayed high yield lup to $90 \%$ ), but a purification by ester extraction was necessary [13]. On the other hand, the esterification of abietic acid with acidic functional ionic liquids (1-(3-sulfonic group) propyl-3-methylimidazole $\mathrm{p}$-toluenesulfonate) as catalyst displayed ca. $90 \%$ conversion; similarly, easy reusability of the catalyst was reported [14].

Most studies on heterogeneous catalysis for this reaction have been conducted with polyols using metal oxides such as calcium oxide, zinc oxide, magnesium oxide, and alumina; they also include alkaline metal hydroxides such as calcium hydroxide; metal salts such as iron choride, calcium formate, calcium phosphonates; ionic liquids (acidic funcionalized); and, rare metal oxides [15, 16]. In particular, studies on the heterogeneous esterification of rosin with methyl alcohol are scarce. Recently, ZnO supported on a fluid catalytic cracking catalyst resid (ZnO/FC3R) was evaluated on the esterification of rosin with methyl alcohol under subcritical $\mathrm{CO}_{2}$ conditions; $\mathrm{CO}_{2}$ acted as an auxiliary catalyst, improving the mass transfer and adjusting $\mathrm{pH}$ to values between 3.54 and 3.91 . Conversion ca. $97 \%$ was obtained at $5 \mathrm{~h}$ reaction time, $220^{\circ} \mathrm{C}$, and without solvent [17]. On the other hand, acidic groups such as p-toluenesulfonic acid were incorporated into MCM-41, achieving high activity in the esterification of rosin with methyl alcohol, i.e., $88 \%$ conversion, at $220^{\circ} \mathrm{C}$ and $5 \mathrm{~h}$ reaction time [18].

In this work, we evaluated different catalysts, solvents, and reaction conditions for the heterogeneous esterification of rosin with methyl alcohol under mild conditions. Low-cost materials acquired in Colombia's local market (i.e., calcium-based material and kaolin) were tested as catalysts of the reaction and compared to commercial magnesium, titanium, and aluminum oxides.

\section{Experimental section}

\subsection{Materials}

Rosin (technical grade: Colophony WW®, $64-78{ }^{\circ} \mathrm{C}$ softening point and $146-169 \mathrm{mg} / \mathrm{g}$ acid number) was supplied by Protokimica (Medellín, Colombia). Methyl alcohol and acetone (Ph. Eur. Reag., purity $>99.0 \%$ ), and analytically pure potassium acid phthalate were purchased from Merck. Potassium hydroxide, toluene, isopropyl alcohol, diethyl ether, ethyl alcohol, and magnesium oxide, all analytically graded, were acquired from JT Baker. Analytical grade Amberlyst $\circledast 15$ and dimethyl carbonate (technical grade), abietic acid methyl ester (analytical assay not available), and tetra-methyl-ammonium hydroxide solution at $25 \mathrm{wt} \%$ in methyl alcohol were purchased from Sigma-Aldrich. Titanium dioxide (Hombikat ${ }^{\circledR}$, analytically pure) was bought from 
Sachtleben Chemie. $\quad \gamma$-Alumina (analytical grade) was supplied by Alpha Aesar. Kaolin, calcium-based material, and calcium carbonate lanalytical assay not availablel were acquired in the local Colombian market.

\subsection{Rosin and reaction product characterization}

Rosin and the reaction products were characterized by GC and GC-MS, based on ASTM D5974-15. Derivatization (i.e., methylation with tetra-methyl-ammonium hydroxide - TMAHI was necessary for individual rosin acids identification; specifically, titration of samples previously diluted in methyl alcohol/diethyl ether solution was carried out with TMAH $6 \%$ wt. titration/methylation solution and phenolphthalein as an indicator. Likewise, the same derivatization procedure was followed for the reaction products. Moreover, quantification was made by the area percent method, according to ASTM D5974-15. GC analysis was performed in an Agilent Technologies 7890 equipped with a flame ionization detector (FID). A $1 \mu \mathrm{L}$ sample was separated using an HP-5 ((5\%-phenyl)-methylpolysiloxane) capillary column (30 m $x 0.32 \mathrm{~mm}$ i.d. $x 0.25 \mu \mathrm{m}$ film thickness) (Agilent $\mathrm{J} \& \mathrm{~W}$ ). Helium was used as a carrier gas with an average linear velocity of $20 \mathrm{~cm} / \mathrm{s}$; the initial temperature $\left(150^{\circ} \mathrm{C}\right)$ was held for $5 \mathrm{~min}$ and, then, a $5^{\circ} \mathrm{C} / \mathrm{min}$ heating ramp up to $250^{\circ} \mathrm{C}$ (held for $10 \mathrm{~min}$ ) was used. The split ratio, inlet injection temperature, and detector temperature were $100: 1,300^{\circ} \mathrm{C}$, and $325^{\circ} \mathrm{C}$, respectively.

Additionally, peak identification was conducted by GC-mass spectrometry (GC-MS) using an Agilent 7890 GC system coupled to Agilent 5975C VL MSD triple quadrupole mass detector. Chromatographic conditions were as above. Electron-impact mass spectra were recorded every second at an electron energy of $70 \mathrm{eV}$. Besides, Fourier-transform infrared (FTIR) spectra of feed and reaction products were performed in a Perkin Elmer Spectrum 65 with a horizontal attenuated total reflectance (HATR) attachment, from 600 to $4,000 \mathrm{~cm}^{-1}$. Finally, reaction products were concentrated by the roto-evaporation technique using a Heidolph V-800 with vacuum control in automatic mode.

\subsection{Catalyst characterization}

XRD patterns of materials were recorded by using a Bruker D8 Advance coupled with $\mathrm{CuK} \alpha 1$ radiation generated at $40 \mathrm{kV}$ and $40 \mathrm{~mA}$, with $2 \theta$ from $5^{\circ}$ to $70^{\circ}$ and a step size of $0.05^{\circ}$. Fourier-transform infrared (FTIR) spectra of catalyst fresh and after reaction were collected in a Perkin Elmer Spectrum 65 on diffuse reflection mode (Pike) with $\mathrm{KBr}$ powder. Additionally, temperature programmed desorption of $\mathrm{CO}_{2}$ was conducted in helium flow at 50
$\mathrm{mL} / \mathrm{min}$ until $850^{\circ} \mathrm{C}$ with a heating ramp of $10^{\circ} \mathrm{C} / \mathrm{min}$ in a Micromeritics Autochem 2920. A previous pretreatment of the samples was performed by heating at $200{ }^{\circ} \mathrm{C}$ for $60 \mathrm{~min}$ with a heating rate of $10^{\circ} \mathrm{C} / \mathrm{min}$ under helium flow of 50 $\mathrm{mL} / \mathrm{min}$.

\subsection{Catalyst activity}

The samples of rosin, methyl alcohol, and catalyst were placed in a flask (50 mL) equipped with temperature control, a condenser, and magnetic stirring. The reaction temperature was maintained at $64^{\circ} \mathrm{C}$ (reflux temperature), and stirring at $500 \mathrm{rpm}$. Different reaction conditions li.e., solvent, reaction time, reactant molar ratio, and catalyst load) were evaluated, and the catalyst was removed by filtration; in some cases, subsequent centrifugation was performed.

The conversion was calculated with the acid value of reactants and products, Equation 1 [19].

$$
\text { Conversion }(\%)=100 \times\left(1-\frac{W n_{\text {Ester }}}{W n_{\text {Rosin }}}\right)
$$

The conversion of rosin was used as a criterion to assess the esterification reaction. The acid value was determined according to ASTM D465-15. The dissolved reaction product lor rosin dissolved in methyl alcohol or isopropyl alcohol/toluene mixture) and 4-5 drops of phenolphthalein indicator was titrated with a standard solution of potassium hydroxide; the titration solution was standardized with potassium acid phthalate solution. The acid number $(W n)$ in $\mathrm{mg} / \mathrm{g}$ was computed as shown in Equation 2,

$$
W n=\frac{V \cdot C \cdot M W}{m}
$$

where $V$ is the volume of potassium hydroxide used in the titration $(\mathrm{mL}), C$ is its concentration (mol/L), $m$ is the weight of the sample $(\mathrm{g})$ and $M W$ is the molecular weight of potassium hydroxide $(56.11 \mathrm{~g} / \mathrm{mol})$.

\subsection{Catalyst stability}

The reusability of the catalyst was assessed by using the catalyst in several reaction cycles under the same reaction conditions. After each cycle, the catalyst was washed under stirring for $1 \mathrm{~h}$ with methyl alcohol at $64^{\circ} \mathrm{C}$, filtered and dried at $100^{\circ} \mathrm{C}$.

\section{Results and discussion}

\subsection{Rosin characterization}

Rosin samples were freshly broken from a larger mass to avoid air oxidation (ASTM D5974-15). The acidity number 
Table 1 Peak identification and quantification for rosin and reaction products

\begin{tabular}{|c|c|c|c|}
\hline \multirow{2}{*}{ Compound } & \multirow{2}{*}{$\begin{array}{l}t_{R} \\
(\min )\end{array}$} & \multicolumn{2}{|c|}{ Concentration $^{\text {a }}$ (\% wt.) } \\
\hline & & Rosin & $\begin{array}{l}\text { Reaction } \\
\text { product }\end{array}$ \\
\hline Methyl alcohol & 2.6 & - & - \\
\hline Methyl pimarate & 33.4 & 2.3 & 3.6 \\
\hline Methyl isopimarate & 35.4 & 11.2 & 10 \\
\hline Methyl levopimarate & 37.6 & 29.7 & 27.8 \\
\hline Methyl dehydroabietate & 38.7 & 19.7 & 18.1 \\
\hline Methyl abietate & 40.1 & 21.1 & 18 \\
\hline Methyl neoabietate & 42.0 & 10.9 & 11.6 \\
\hline Others & - & 5.1 & 10.9 \\
\hline
\end{tabular}

$t_{R}$ is the retention time. ${ }^{a}$ Solvent-free basis

of rosin, as measured with several samples of different weight ( 0.5 to $4.0 \mathrm{~g})$ by using different concentrations of the titration solution $(0.08,011$, and $0.49 \mathrm{~mol} / \mathrm{L})$, ranged from $145.3 \mathrm{mg} / \mathrm{g}$ to $146.0 \mathrm{mg} / \mathrm{g}$, with an average value of 145.6 $\mathrm{mg} / \mathrm{g}$, indicating the reproducibility and accuracy of the acid numbers obtained by starting from different amounts of sample. The main components of rosin were properly separated, as indicated by the well-defined peaks observed in chromatograms. The components of rosin lidentified by comparison between mass spectra for each peak and NIST databasel and their concentration are presented in Table 1.

The concentration of rosin is similar to that produced in Central America [20], with levopimaric, dehydroabietic, and abietic acids as main compounds. In addition, elution times in Table 1 are in good agreement with Hudy [21] and Volkman and coworkers [22]. Hudy [21] used polar and nonpolar packed columns for the separation of resin acid esters, obtaining similar results with both columns. Furthermore, the differences in volatility and unsaturation of resin acid esters are the key to the separation, which is not achieved with rosin acids without esterification. Volkman and coworkers [22] reported a successful separation of the main resin acids; the elution in a nonpolar column (HP-1 methyl silicone capillary column) followed the order: pimaric, isopimaric, levopimaric, dehydroabietic, abietic, and neoabietic resin acid esters.

FTIR spectrum of rosin is shown in Figure 1a. The peak at $1,275 \mathrm{~cm}^{-1}$ is assigned to the stretching vibration of the carboxylic group ( $\mathrm{C}-0$ bond), while bands at 1451 and $888 \mathrm{~cm}^{-1}$ can be attributed to the bending vibration of the same group $(\mathrm{O}-\mathrm{H})$ [19]. The intense band at $1,694 \mathrm{~cm}^{-1}$ is assigned to the carbonyl structure $(\mathrm{C}=0)$ of carboxyl groups $[19,23]$. Additionally, the bands at 2,927 and $3,434 \mathrm{~cm}^{-1}$ can be assigned to stretching vibration of the hydroxyl group of adsorbed water and vibrations typical for hydrocarbons, respectively $[23,24]$. These bands have been commonly reported for rosin [25].

\subsection{Characterization of the product of esterification of rosin}

The reaction product obtained with toluene as solvent (methyl alcohol to toluene at 1:0.4 volume ratio), rosin to methyl alcohol molar ratio of $1: 186,64^{\circ} \mathrm{C}, 3 \mathrm{~h}$, and calcium-based material loaded at $40 \%$ with respect to rosin, was analyzed by FTIR and GC-MS (following the same procedure than rosin characterization). Thus, the concentration of reaction products obtained by GC analysis is shown in Table 1 (right column). The concentration of reaction products is similar to that of rosin, indicating that all components of rosin are transformed into ester products in the reaction.

FTIR spectrum of the product of esterification of rosin is compared with that of abietic acid methyl ester (AAME std), Figure $1 \mathrm{~b}$. A broad band at $3,334 \mathrm{~cm}^{-1}$ is observed for both AAME and the reaction product, as well as for rosin (see Figure 1a), and can be attributed to the hydroxyl group of adsorbed water. FTIR spectrum for AAME displays an intense band at $1,727 \mathrm{~cm}^{-1}$ assigned to stretching vibration of carbonyl structure $(\mathrm{C}=0)$; the sharp peak at $1,244 \mathrm{~cm}^{-1}$ is assigned to the stretching vibration of $\mathrm{C}-\mathrm{O}$ bond from ester group [26]. Since IR spectra for methyl ester of rosin compounds are not available in the literature, a simulation of the molecule was carried out. The optimization of the AAME geometry was performed using the Density Functional Theory (DFT) with the hybrid functional B3YLP and the electronic base 6-31G with Gaussian G09. Intense bands at 1,727 and $1,244 \mathrm{~cm}^{-1}$ were obtained for both elucidated and experimental IR spectra.

FTIR spectrum for reaction product in Figure $1 \mathrm{~b}$ shows the same bands as AAME, at 1,727 and $1,244 \mathrm{~cm}^{-1}$. Additionally, bands at 3,670 and $3,329 \mathrm{~cm}^{-1}$, typical for methyl alcohol lassigned to the stretching vibration of hydroxyl group [25]), are due to unreacted methyl alcohol. On the other hand, the presence of an aromatic ring in the reaction product was evidenced by some typical bands. 


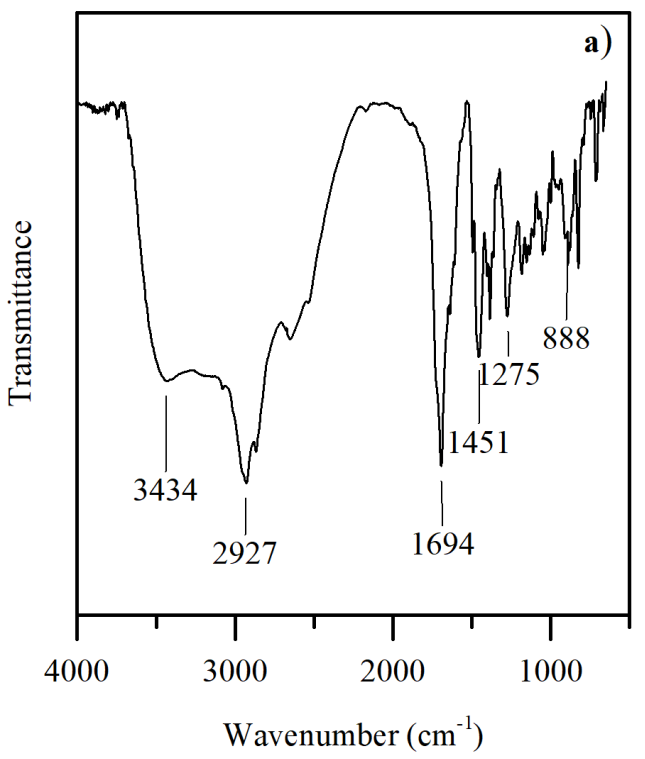

(a)

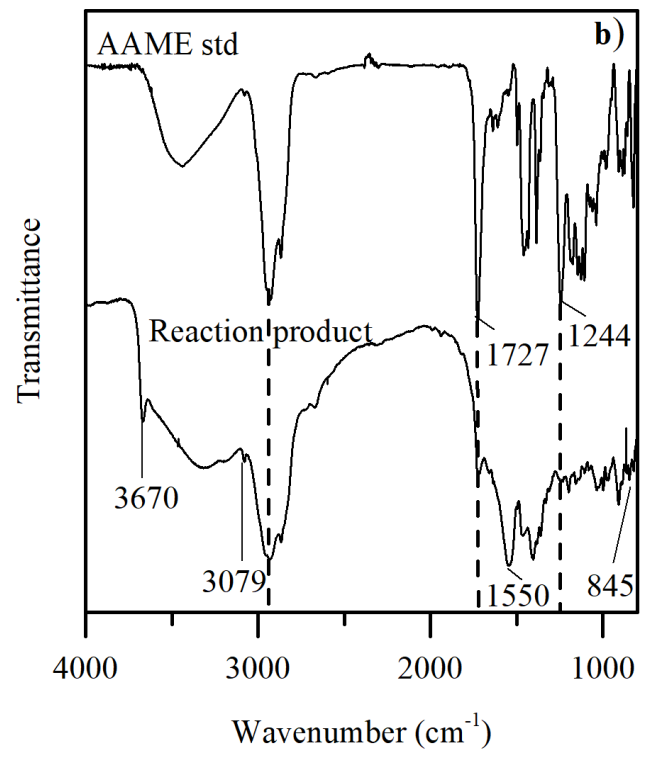

(b)

Figure 1 FTIR spectra of a) rosin and, b) reaction product and commercial abietic acid methyl ester (AAME std). Reaction conditions: $64^{\circ} \mathrm{C}, 3 \mathrm{~h}$, rosin to methyl alcohol molar ratio of $1: 186$, methyl alcohol to toluene volumetric ratio of $1: 0.4$, and calcium material loaded at $40 \%$ is weight basis with respect to

rosin

The slight peak at $3,079 \mathrm{~cm}^{-1}$ is assigned to the stretching vibration of $\mathrm{C}-\mathrm{H}$ bond. The band at $1,550 \mathrm{~cm}^{-1}$ is assigned to the stretching vibration of $\mathrm{C}-\mathrm{C}$ bond. Finally, the slight peak at $845 \mathrm{~cm}^{-1}$ is assigned to the out-of-plane bending of $\mathrm{C}-\mathrm{H}$ bond [26]. Indeed, low amounts of methyl alcohol and toluene are expected in the reaction product, in agreement with the low area of the corresponding peaks.

\subsection{Activity of different catalysts}

Figure $2 \mathrm{a}$ shows the activity of calcium-based material la mixture of $\mathrm{CaO}, \mathrm{Ca}(\mathrm{OH})_{2}$ and $\left.\mathrm{CaCO}_{3}\right)$, magnesium oxide, titanium dioxide, alumina, kaolin, and Amberlyst $15 \AA$ at different loads (with respect to rosin) for the esterification of rosin with methyl alcohol. Amberlyst ${ }^{\circledR} 15$ does not display activity for the reaction, suggesting that acidity does not promote the formation of esters at heterogeneous conditions. Conversely, the basic materials tested in this work have a significant effect, in agreement with other reports $[17,19]$. A similar performance was displayed by magnesium oxide and titanium dioxide; both catalysts have the best performance at $20 \%$ catalyst load, achieving 23-27\% conversion. Furthermore, conversion decreases at higher catalyst loads, probably due to diffusional effects resulting from the high density and high loads of these materials [27, 28]. After an initial increase with catalyst load, conversion with alumina and kaolin decreases until $20 \%$ catalyst load to increase again, reaching 15 and $23 \%$ conversion, respectively, at a $40 \%$ catalyst load. The calcium-based material outperforms all the other materials; conversion is directly proportional to catalyst load and reaches $46 \%$ at $40 \%$ catalyst load. The high activity of this material would be related to its basicity and/or the higher $\mathrm{pH}$ of the slurry [29].

\subsection{Solvent effect}

Acetone, toluene, and methyl, ethyl, and isopropyl alcohols were evaluated as solvents in the esterification of rosin with methyl alcohol when a calcium-based material as a catalyst was used. As shown in Figure 2b, a slight increase in rosin conversion (ca. 5\%) with ethyl alcohol was obtained in relation to the reaction without solvent. On the other hand, acetone and isopropyl alcohol displayed similar performance on the esterification of rosin, with conversions smaller than the base case (i.e., no solvent). Thus, high basicity and polarity would be desirable for a solvent in the esterification of rosin; indeed, according to the polarity $\beta$ parameter of Kamlet-Taft $\left(E_{T}^{N}\right)$, polarity decreases in the order methyl alcohol>ethyl alcohol>isopropyl alcohol>acetone, whereas according to the $\beta$ parameter of Kamlet-Taft the basicity decreases in the order isopropyl alcohol>ethyl alcohol> methyl alcohol>acetone [30]. However, since toluene (nonpolar solvent) displayed an adverse effect on the calcium-based material, stability tests were performed with this solvent (see below).

Conversions of rosin with toluene as solvent and magnesium oxide and calcium carbonate as catalysts are low, around 7 and $30 \%$, respectively (see Figure $2 \mathrm{~b}$ ). Calcium carbonate is a highly basic material with strong basic sites [31]. On the other hand, magnesium oxide possesses medium-strength sites attributed to the $\mathrm{Mg}$ 


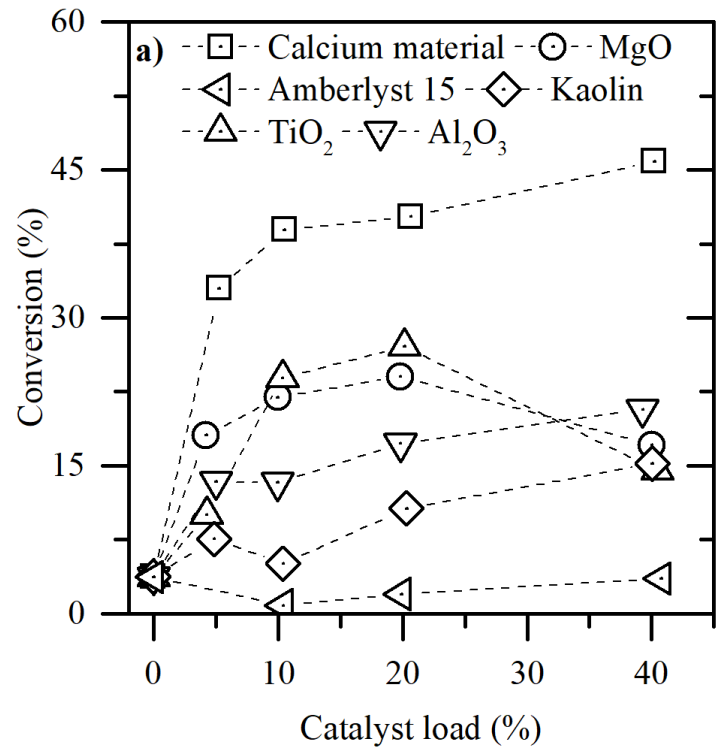

(a)

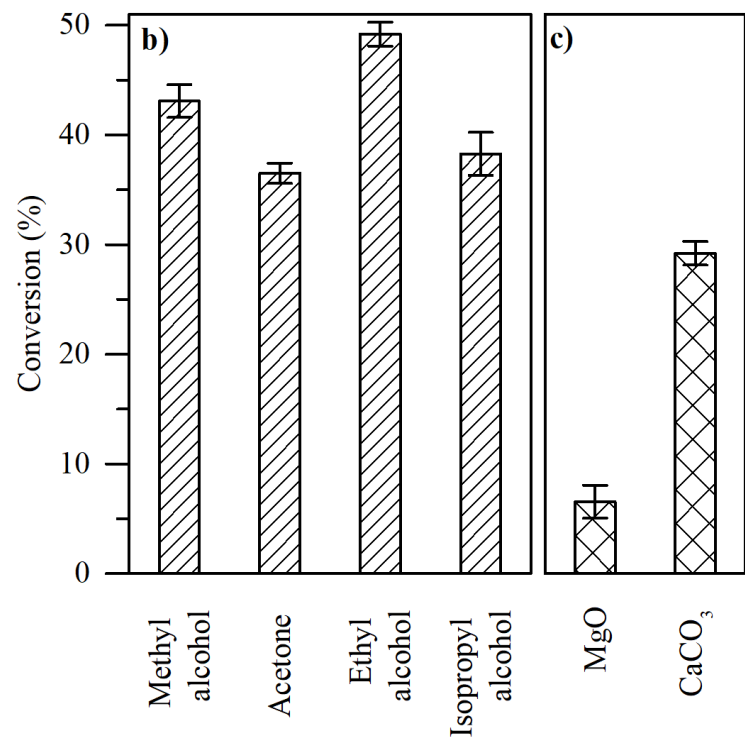

(b)

Figure 2 Effect of catalysts and solvents on the esterification of rosin at $64^{\circ} \mathrm{C}$ : al Activity of the different catalysts without solvent (catalyst load is respect to rosin); conversion without a catalyst is ca. $4 \%$; reaction conditions were $3 \mathrm{~h}$ and rosin to methyl alcohol molar ratio of $1: 748, b)$ activity of different solvents with the calcium-based material as a catalyst, and c) catalyst activity with toluene as solvent. Reaction conditions for tests with solvents were: $4.5 \mathrm{~h}$, rosin to methyl alcohol molar ratio of 1:187 and methyl alcohol to solvent volumetric ratio of 1:1.76

-0 pair [31]. Therefore, the combination of materials with medium- and high-strength basicity with low-polarity solvents appears insufficient to activate the acid groups of rosin, and /or hydroxyl group of methyl alcohol.

A stability test of the calcium-based material with toluene as solvent was performed. FTIR spectra and XRD patterns for samples of the calcium-based material before and after reaction are shown in Figure 3. FTIR spectrum of the fresh sample of the calcium-based material, Figure 3 a, depicts a sharp band at $3,643 \mathrm{~cm}^{-1}$ associated with the stretching vibrations of $\mathrm{OH}$ groups of $\mathrm{Ca}(\mathrm{OH})_{2}$ [32] and two bands at 1,452 and $876 \mathrm{~cm}^{-1}$ attributed to $\mathrm{CO}_{3}{ }^{2-}$ species from $\mathrm{CaCO}_{3}$ [33], indicating that calcium carbonate and calcium hydroxide are the main phases of this material. In addition, the fact that the band at $3,643 \mathrm{~cm}^{-1}$ decreases until it is practically absent after the second cycle of reaction, indicates that $\mathrm{Ca}(\mathrm{OH})_{2}$ phase disappears from the bulk of the calcium-based material. During catalytic tests with calcium-based material as catalyst and toluene as solvent, $\mathrm{Ca}(\mathrm{OH})_{2}$ phase may be removed from the catalyst, affecting the quantification of the acidic number.

XRD patterns of samples of calcium-based material at different cycles of esterification of rosin with methyl alcohol and toluene as solvent are presented in Figure $3 \mathrm{~b}$. The fresh sample of the calcium-based material shows a main peak at $25.9^{\circ}$, indicating that calcite $\left(\mathrm{CaCO}_{3}\right)$ is the major phase of the material [34]. Calcium oxide and hydroxide, represented by peaks at $2 \theta$ values of $18,46.8,50.1$, and $62,6^{\circ}$ [34], and 28.7, 34.1, 54.8, and $64.8^{\circ}$, respectively $[34,35]$, would be present in lower concentrations. Similarly to FTIR spectra, XRD patterns of catalysts after reusing show differences respect to fresh catalyst analysis. In particular, at the end of the second reaction cycle, the catalyst is composed only of calcium carbonate; the peaks of $\mathrm{CaO}$ and $\mathrm{Ca}(\mathrm{OH})_{2}$ phases are almost absent from the sample. The temperature-programmed desorption profiles with $\mathrm{CO}_{2}$ for samples of calcium-based material before and after reaction with toluene as solvent are shown in Figure 4. TPD- $-\mathrm{CO}_{2}$ profile of the fresh sample displays three peaks around $300-320,370-400$, and $700-750^{\circ} \mathrm{C}$. According to XRD and FTIR results, these peaks can be attributed to $\mathrm{CaO}, \mathrm{Ca}(\mathrm{OH})_{2}$, and $\mathrm{CaCO}_{3}$, respectively. Therefore, the strongest base sites in the sample of calcium material are due to the presence of carbonate. $\mathrm{Ca}(\mathrm{OH})_{2}$ phase is represented by other strong base sites llower than that for carbonate), and medium-strength base sites (with low availabilityl are due to $\mathrm{CaO}$ phase.

The peak between 300 and $450{ }^{\circ} \mathrm{C}$ in the TPD-CO profiles decreases with the number of reaction cycles, suggesting a reduced availability of $\mathrm{Ca}(\mathrm{OH})_{2}$ phase, in agreement with the FTIR and XRD results, perhaps as a result of the very low polarity of toluene facilitating the dissolution of calcium hydroxide. Simultaneously, the area of the peak at $700{ }^{\circ} \mathrm{C}$ increased, which is consistent with the leaching of $\mathrm{Ca}(\mathrm{OH})_{2}$ phase. Structural changes of calcium-based material suggest that solvent/catalyst system toluene/calcium-hydroxide is not suitable for the 


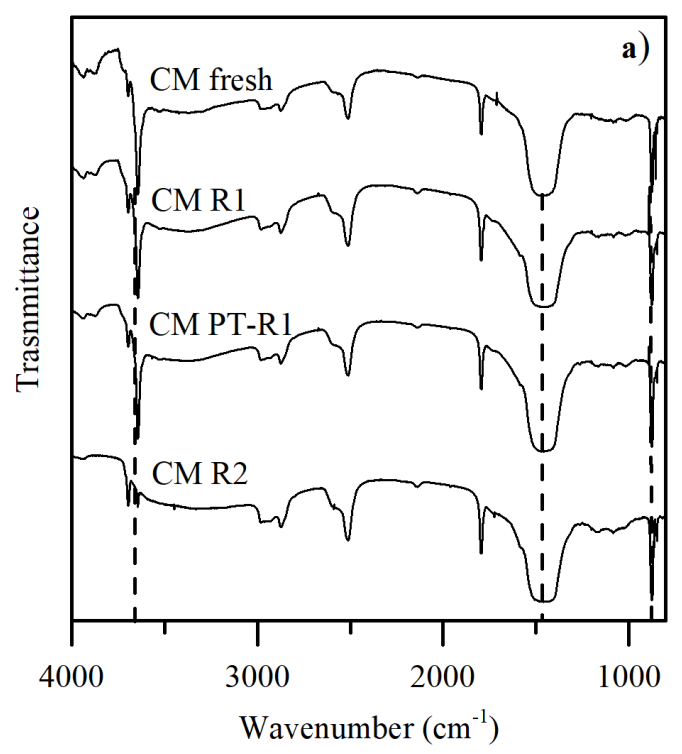

(a)

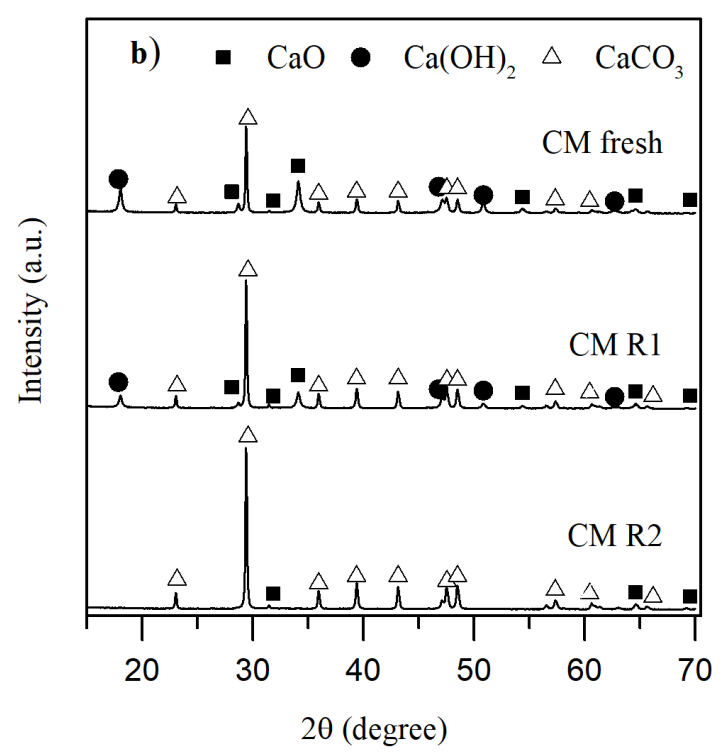

(b)

Figure 3 a) FTIR spectra and b) XRD patterns of calcium-based material: fresh (CM fresh), after first reaction (CM R1), after washing treatment post first reaction (CM PT-R1), and after second reaction (CM R2), with toluene as solvent. Reaction conditions: $64^{\circ} \mathrm{C}, 3 \mathrm{~h}$, rosin to methyl alcohol molar ratio of 1:186, methyl alcohol to toluene volumetric ratio of 1:0.4, and a $40 \%$ load of calcium-based material (with respect to rosin]

esterification of rosin with methyl alcohol. Furthermore, the conversion of rosin with the toluene/calcium-carbonate system is low, suggesting that the calcium hydroxide phase plays an important role in the esterification of rosin.

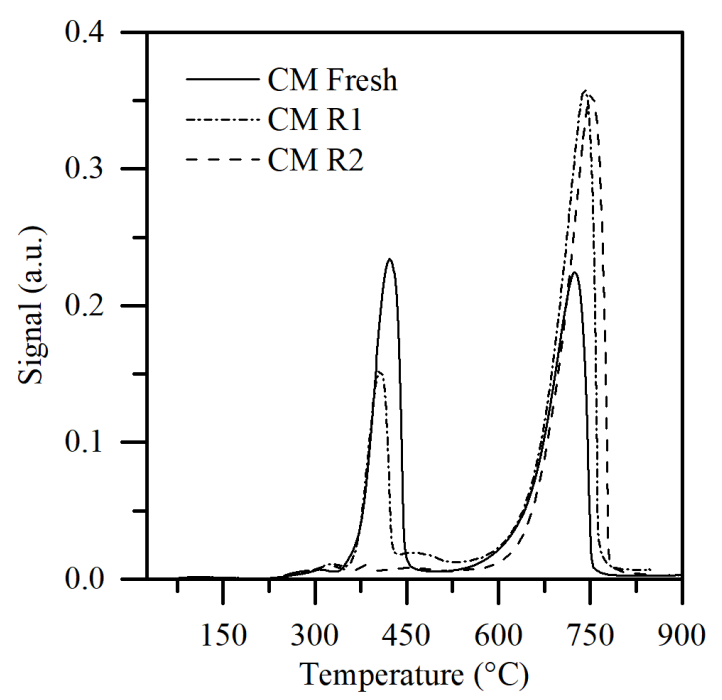

Figure $4 \mathrm{TPD}-\mathrm{CO}_{2}$ of calcium-based material: fresh (CM Fresh), and after first (CM R1) and second reaction (CM R2), with toluene as solvent

\subsection{Activity of the calcium-based material without solvent}

Minor influence of the solvent on the esterification of rosin was observed (i.e., conversion increased by $5 \%$ with ethyl alcohol). Furthermore, avoiding subsequent separation of solvents is desirable in a synthesis process. Thus, different reaction times and ratios of reactants were evaluated to obtain improved reaction conditions for the esterification of rosin with methyl alcohol without solvent and using the calcium-based material as a catalyst. Esterification of the main components of rosin (Table 1) with methyl alcohol is schematized in Figure 5. As the stoichiometric ratio of rosin compounds and methyl alcohol is $1: 1$, the formation of rosin ester would be favored by an excess of methyl alcohol; therefore, the rosin to methyl alcohol molar ratio was varied.

Conversion of rosin at different rosin to methyl alcohol molar ratios without solvent is shown in Figure 6a; at 1:187 rosin to methyl alcohol molar ratio, the conversion is ca. $55 \%$, while the other ratios tested display similar values (ca. 45\%). After an initial increase, conversion stabilizes to ca. $45 \%$ at high reactant ratios, perhaps due to the competition of molecules to reach the active sites on the catalyst (see Figure 6a). On the other hand, in esterification reactions at lower reactant ratios, dissolution of rosin is difficult, which may explain the reduction in catalyst activity at 1:97; therefore, experiments were not performed at lower rosin to methyl alcohol molar ratios. Similarly, the large variation in the conversion of rosin at 1:97 rosin to methyl alcohol molar ratio $12.8 \%$ standard deviation in conversion) would be explained by this dissolution effect. 


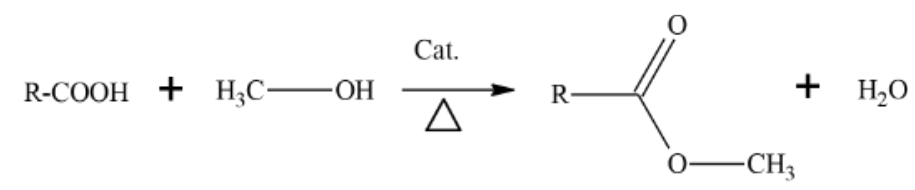

where the acids $\mathrm{R}-\mathrm{COOH}$ are:

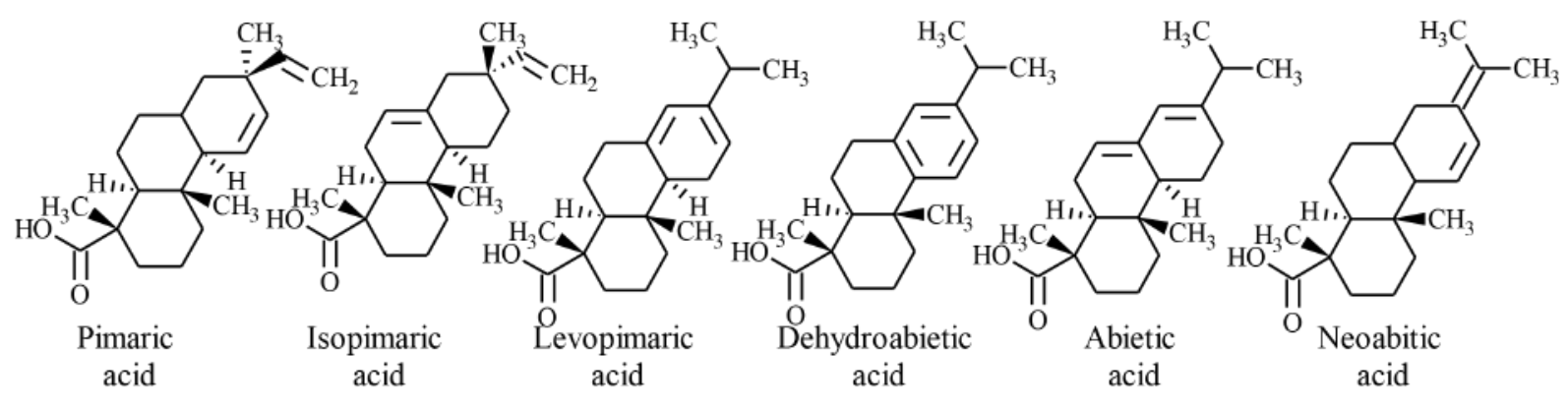

Figure 5 Scheme of rosin esterification reaction with methyl alcohol

Figure $6 \mathrm{~b}$ shows the conversion of rosin as a function of time. At $1 \mathrm{~h}$ the conversion is ca. $40 \%$, and a (somewhat) constant conversion of ca. $45 \%$ is achieved after $3.5 \mathrm{~h}$ of reaction, indicating that there is little gain in increasing the reaction time. As a result of the steric effects of tricyclic skeleton of rosin compounds, the position of carboxyl group (located on a tertiary carbon atom) and low molecular size of methyl alcohol with respect to rosin, esterification reactions typically involve severe conditions, such as high temperatures and pressures and long reaction times, to reach high conversions $[17,18]$.

A $55 \%$ conversion of rosin can be achieved with the calcium-based material as a heterogeneous catalyst at $3.5 \mathrm{~h}$ reaction time, rosin to methyl alcohol molar ratio of $1: 187,64^{\circ} \mathrm{C}, 500 \mathrm{rpm}$ stirring, and $40 \%$ catalyst load. However, a separation step would be required to purify the esters, for instance, by liquid-liquid extraction and column chromatography, as previously reported, even for esterification of rosin at severe conditions $[13,36]$.

\subsection{Catalyst stability}

Five reaction cycles were carried out to evaluate the stability of the calcium-based material in the esterification of rosin with methyl alcohol and without solvent, Figure 7. Fresh rosin and methyl alcohol were added to the catalyst at the beginning of each cycle to keep the same molar ratio in all cycles. The procedure was repeated with different amounts of initial catalyst to analyze the reproducibility of the experiment. Conversion of rosin decreased by ca. $50 \%$ in the second cycle, see Figure 7. A slight increase in the conversion of rosin is observed for the remaining cycles, suggesting that the procedure implemented to wash the catalyst is not enough to remove the compounds adsorbed on the surface of the calcium-based material, but repetitive washing probably removes more adsorbed material.

FTIR and XRD analyses were performed on the catalyst samples in the stability tests, Figure 8. FTIR spectra of a sample of the calcium-based material after reaction without solvent and a sample of washed calcium material after reaction were compared with a fresh sample, Figure 8a. Although the spectra are similar for the fresh and used samples, some differences can be observed. The band at 2,928 $\mathrm{cm}^{-1}$ lattributed to the carboxylic group of rosin and carbonyl structure of ester groupl is larger for the sample of the calcium-based material after the reaction than the other samples, which may suggest the presence of unreacted rosin and/or rosin methyl ester on the surface of the catalyst after the reaction. After reaction and washing, the band of FTIR spectrum at $2,928 \mathrm{~cm}^{-1}$ is reduced, but it is not equal to that of the fresh catalyst, suggesting that some rosin and/or rosin methyl ester are poisoning the material after the washing step.

No significant difference in the XRD pattern of the calcium-based material is observed after the first reaction cycle, see Figure 8b, whereas after five reaction cycles, an appreciable reduction in the intensity of peaks associated to $\mathrm{Ca}(\mathrm{OH})_{2}\left(17.86,46.8\right.$ and $\left.50.86^{\circ}\right)$ and $\mathrm{CaO}$ phases $(31.86$, 34.11 and $54.37^{\circ}$ ) is evidenced, suggesting leaching of these phases. Both the presence of some amounts of the unreacted rosin and/or the reaction product adsorbed onto the catalyst, and the leaching of some phases of the catalyst, strongly affect the performance of the calcium 


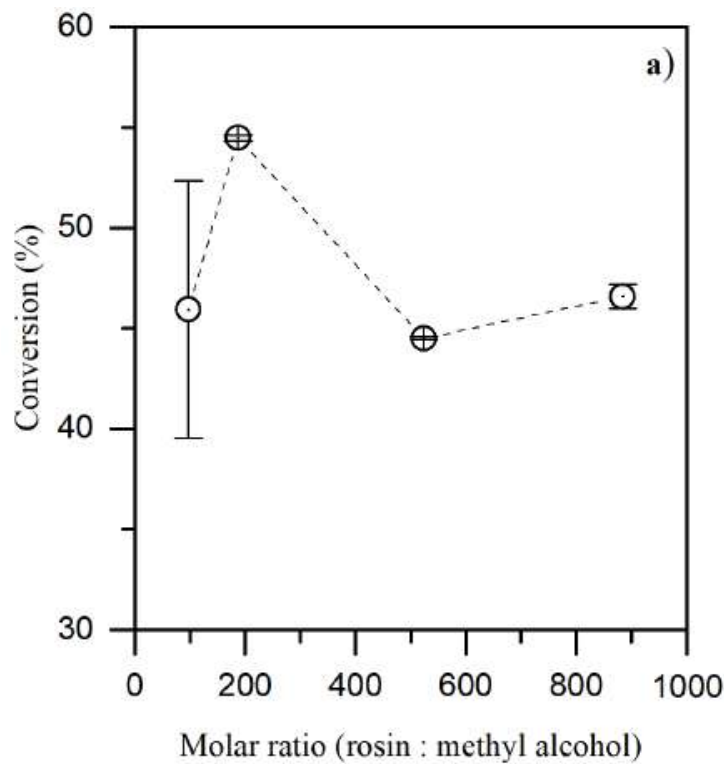

(a)

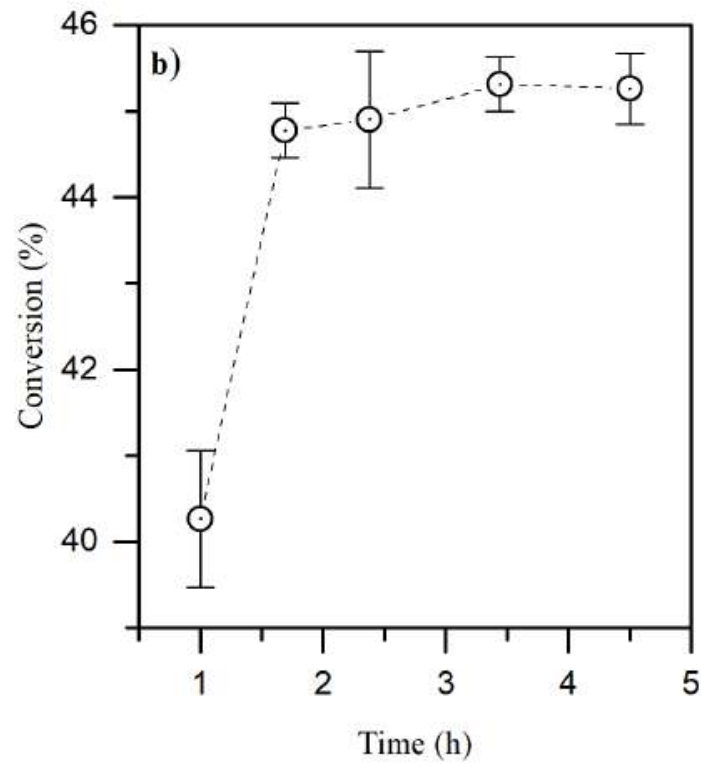

(b)

Figure 6 Performance of esterification of rosin at $64^{\circ} \mathrm{C}$ and $40 \%$ of load of calcium-based material with respect to rosin as a function of al reactants ratio (at $4.5 \mathrm{~h}$ ), and b) time (at rosin to methyl alcohol molar ratio of 1:5231

material. In spite of the catalyst, deactivation can be offset by the low cost of the calcium-based material, future works can be addressed to obtain materials with medium-strength basic sites as a part of the structure of the catalyst or strongly attached to the catalyst material.

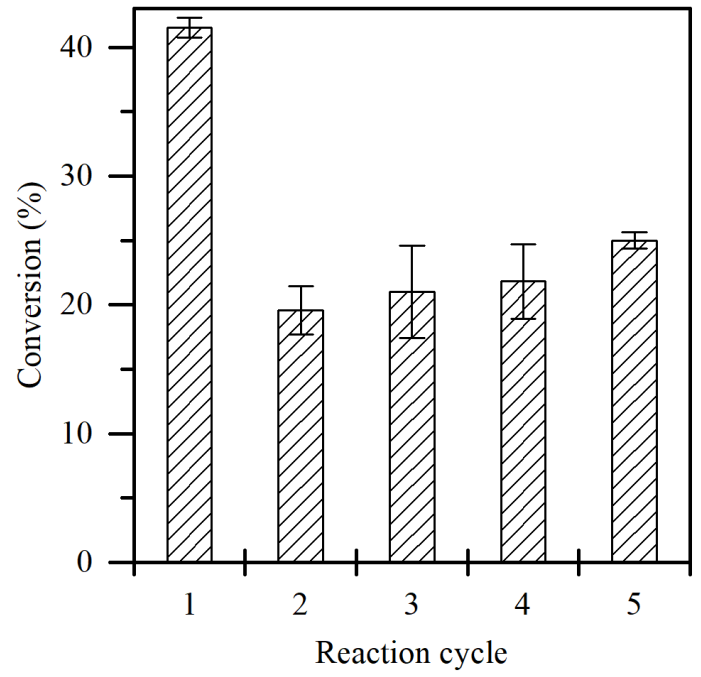

Figure 7 Catalyst stability. Reaction conditions: $64^{\circ} \mathrm{C}, 500 \mathrm{rpm}$, $2.5 \mathrm{~h}, 40 \%$ catalyst load (with respect to rosin) and rosin to methyl alcohol molar ratio of 1:187 and without solvent

\section{Conclusions}

The esterification reaction of rosin with methyl alcohol without solvent is promoted by basic solids. The strength of basic sites can be an important property of the catalyst to reach high activity. Although calcium carbonate has high-strength basicity, catalysts with lower strength, such as materials with calcium hydroxide and calcium oxide phases, showed better performance. No significant effect was found with the tested solvents.

A sample of a calcium-based material composed mainly of calcium carbonate and calcium hydroxide displays high activity in the esterification of rosin. This catalyst is a low-cost and easily affordable material, in contrast to other complex materials reported in the literature. In addition, other procedures have been performed at severe conditions (temperatures $>200^{\circ} \mathrm{C}$ and reaction times $>24$ $h$, even at high pressure), and at these conditions, the conversion of rosin is not complete; thus, a subsequent separation step is necessary.

Under reaction conditions tested in the present work and using toluene as solvent, $\mathrm{Ca}(\mathrm{OH})_{2}$ phase of the calcium-based material can be dissolved into the reaction matrix, as evidenced by FTIR, TPD- $\mathrm{CO}_{2}$, and XRD analysis, suggesting that toluene is not a suitable solvent for this reaction system. In addition, the dissolved species can interact with rosin, affecting the reaction, and/or the quantification of conversion by means of the acidic number. 


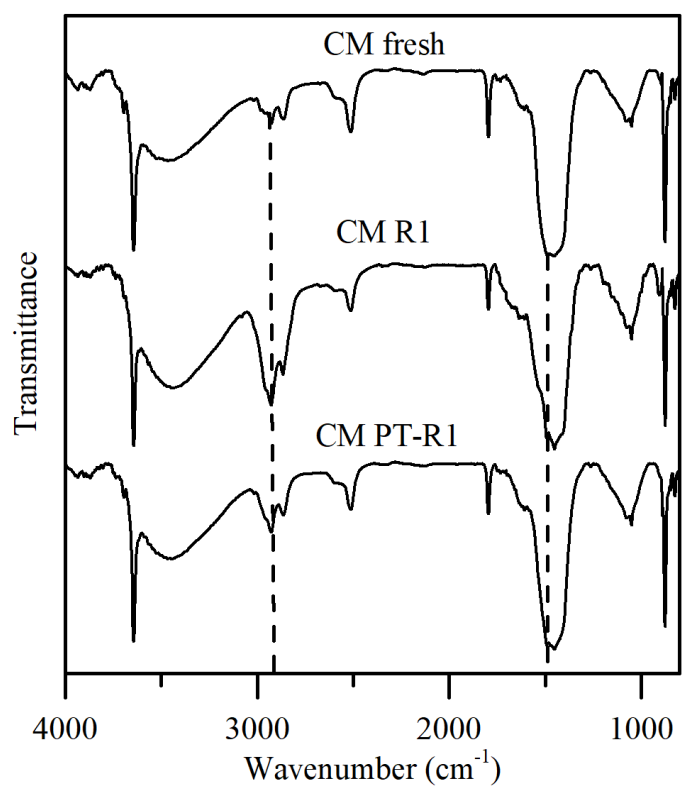

(a)

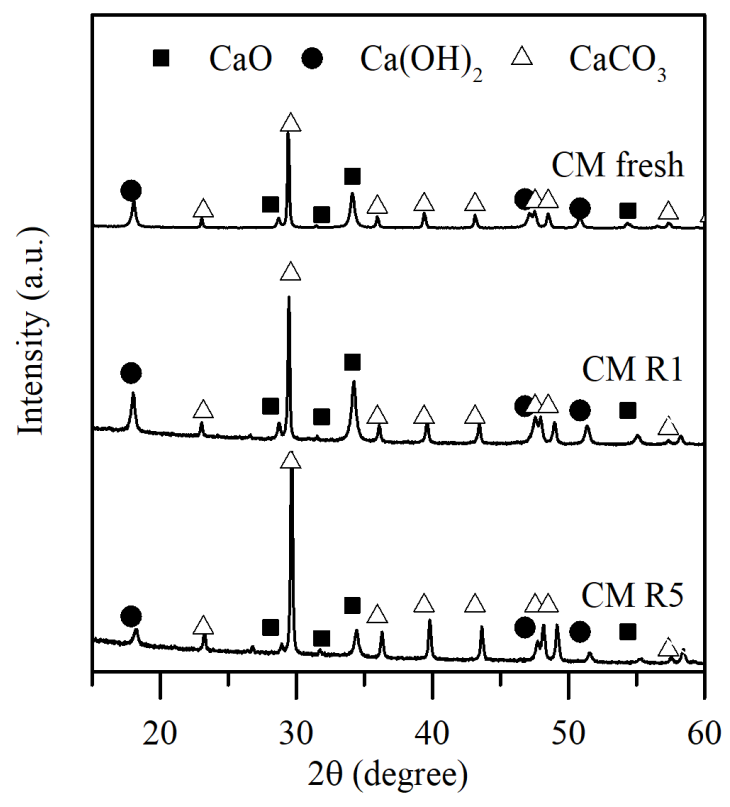

(b)

Figure 8 a) FTIR spectra and b) XRD patterns for samples of calcium-based material: fresh (CM fresh), and after the first reaction (CM R1), washing (CM PT-R1), and $5^{\text {th }}$ reaction cycle

(CM R5); the reaction was conducted without solvent

\section{Declaration of competing interest}

We declare that we have no significant competing interests, including financial or non-financial, professional, or personal interests interfering with the full and objective presentation of the work described in this manuscript.

\section{Acknowledgements}

The authors acknowledge the financial support of Universidad de Antioquia through project PRG2014-1091. D.G. acknowledges to MINCIENCIAS scholarship, call 727 of 2015 .

\section{References}

[1] R. Höfer, "The pine biorefinery platform chemicals value chain," in Industrial biorefineries \& white biotechnology, A. Pandey, R. Höfer, M. Taherzadeh, M. Nampoothiri, and C. Larroche, Eds. Amsterdam, NL: Elsevier, 2015, pp. 127-155.

[2] I. T. Clark and E. E. Harris, "Catalytic cracking of rosin"," J. Am. Chem. Soc., vol. 74, no. 4, February 1 1952. [Online]. Available: https://doi.org/10.1021/ja01124a046

[3] J. Mikulec, A. Kleinová, J. Cvengroš, L. Joríková, and M. Banič, "Catalytic transformation of tall oil into biocomponent of diesel fuel," Int. J. Chem. Eng., vol. 2012, March 2012. [Online]. Available: https://doi.org/10.1155/2012/215258

[4] J. M. Anthonykutty and et al, "Value added hydrocarbons from distilled tall oil via hydrotreating over a commercial NiMo catalyst," Ind. Eng. Chem. Res., vol. 52, no. 30, July 2 2013. [Online]. Available: https://doi.org/10.1021/ie400790v

[5] A. Bernas, T. Salmiand, D. Y. Murzin, J. P. Mikkola, and M. Rintola, "Catalytic transformation of abietic acid to hydrocarbons," Top. Catal., vol. 55, no. 7-10, July 2012. [Online]. Available: https: //doi.org/10.1007/s11244-012-9846-7

[6] D. García and et al, "Improvements of thermal and thermochemical properties of rosin by chemical transformation for its use as biofuel," Waste and Biomass Valorization, vol. 11, November 2020. [Online]. Available: https://doi.org/10.1007/s12649-019-00863-y

[7] N. Xiao, J. Jian, D. Wei, and C. Xia, "Study on synthesis and properties of biodiesel oil from rosin," Chem. Ind. For. Prod., vol. 27, no. 4, pp. 79-81, 2012.

[8] M. Ash and I. Ash, Handbook of Paint and Coating Raw Materials, 2nd ed. Endicott, USA: Synapse Information Resources Inc, 2013.

[9] M. Ash, Handbook of Plastics and Rubber Additives, 2nd ed. Endicott, USA: Synapse Information Resources Inc, 2004.

[10] A. Wypych, Databook of Plasticizers, 2nd ed. Toronto, CA: ChemTec Publishing, 2017.

[11] R. Lewis, Sax's Dangerous Properties of Industrial Materials, 12th ed. New York, USA: John Wiley \& Sons, 2012.

[12] E. P. Hurtado and A. L. Villa, "Kinetics of nopyl acetate synthesis by homogeneously catalyzed esterification of acetic acid with nopol," Revista Facultad de Ingeniería Universidad de Antioquia, no. 89, October 2 2018. [Online]. Available: http://dx.doi.org/10.17533/ udea.redin. $\mathrm{n} 89 \mathrm{a} 03$

[13] W. L. Boatright and A. D. Crum, "Nonpolar-volatile lipids from soy protein isolates and hexane-defatted flakes," J. Am. Oil Chem. Soc., vol. 74, April 1997. [Online]. Available: http://dx.doi.org/10.1007\% 2Fs11746-997-0107-z

[14] L. Shi, Y. Shi, L. Fu, X. Cong, and Z. Peng, "Synthesis of methyl abietate catalyzed by acidic functional ionic liquid sulfonic alkylimidazole p-toluenesulfonate," Chemistry and Industrial of Forest Products, vol. 27, no. S1, pp. 11-14, Mar. 2007.

[15] P. Mäki, B. Holmbom, T. Salmi, and D. Y. Murzin, "Recent progress in synthesis of fine and specialty chemicals from wood and other biomass by heterogeneous catalytic processes," Catal. Rev. Sci. Eng., vol. 49, no. 3, June 13 2007. [Online]. Available: https://doi.org/10.1080/01614940701313127

[16] J. D. Hind, T. T. Kanno, and C. S. Miner, "Ester gum by esterification of rosin with glycerol," Ind. Eng. Chem., vol. 46, no. 3, March 11954. [Online]. Available: https://doi.org/10.1021/ie50531a021

[17] X. Wang and et al, "Catalytic methyl esterification of colophony over $\mathrm{ZnO} / \mathrm{SFCCR}$ with subcritical $\mathrm{CO}_{2}$ : Catalytic performance, reaction 
pathway and kinetics," R. Soc. open Sci., vol. 5, no. 5, May 2018 [Online]. Available: https://doi.org/10.1098/rsos.172124

[18] Y. Liu and et al, "Synthesis of rosin methyl ester using PTSA/ZrO2/Mo-MCM-41 mesoporous molecular sieves," Catal. Letters, vol. 149, no. 2, July 2019. [Online]. Available: https://doi.org/10.1007/s10562-019-02782-y

[19] L. Wang and et al, "A supported nano ZnO catalyst based on a spent fluid cracking catalyst (FC3R) for the heterogeneous esterification of rosin," React. Kinet. Mech. Catal., vol. 119, no. 1, April 2016. [Online]. Available: https://doi.org/10.1007/s11144-016-1022-9

[20] D. F. Zinkel and J. Rusell, Naval stores: Production, chemistry, utilization. New York, USA: Pulp Chemicals Association, 1989.

[21] J. A. Hudy, "Resin acids. Gas chromatography of their methyl esters," Anal. Chem., vol. 31, no. 11, November 1 1959. [Online]. Available: https://doi.org/10.1021/ac60155a017

[22] J. K. Volkman, D. G. Holdsworth, and D. E. Richardson, “Determination of resin acids by gas chromatography and high-performance liquid chromatography in paper mill effluent, river waters and sediments from the upper Derwent Estuary, Tasmania," J. Chromatogr. A, vol. 643, no. 1-2, July 23 1993. [Online]. Available: https://doi.org/10.1016/0021-9673(93)80555-M

[23] A. Montenegro and J. E. Rodríguez, "Synthesising highly reactive Tin oxide using Tin(II) 2-ethylhexanoate polynucleation as precursor," Ing. e Investig., vol. 29, no. 1, pp. 47-52, Jan. 2009.

[24] E. K. Plyler, "Infrared Spectra of Methanol, Ethanol, and n-Propanol," J. Res. Natl. Bur. Stand., vol. 48, no. 4, pp. 281-286, Apr. 1952.

[25] M. Mandal, P. Borgohain, P. Begum, R. C. Deka, and T. K. Maji, "Property enhancement and DFT study of wood polymer composites using rosin derivatives as co-monomers," New J. Chem, vol. 42, no. 3, January 2018. [Online]. Available: https: //doi.org/10.1039/C7NJ03825A

[26] R. T. Morrison and R. N. Boyd, Química orgánica, 5th ed. Nucalpan de Juarez, MEX: Pearson Educación, 1998.

[27] M. Becerra, A. Centeno, and S. A. Giraldo, "Triglyceride transesterification in heterogeneous reaction system with calcium oxide as catalyst," Revista Facultad de Ingeniería Universidad de Antioquia, no. 57, pp. 7-13, Jan. 2011.
[28] M. J. Varady, "Fuel reformation and hydrogen generation in direct droplet impingement reactors," Ph. D. dissertation, School of Mechanical Engineering, Georgia Institute of Technology, Atlanta, Georgia, 2010.

[29] G. Wypych, Handbook of Fillers, 3rd ed. Toronto, CA: ChemTec Publishing, 2010.

[30] P. G. Jessop, D. A. Jessop, D. Fua, and L. Phan, "Solvatochromic parameters for solvents of interest in green chemistry," Green Chemistry, vol. 14, no. 5, 2012. [Online]. Available: https://doi.org/ 10.1039/C2GC16670D

[31] S. Yan, H. Lu, and B. Liang, "Supported $\mathrm{CaO}$ catalysts used in the transesterification of rapeseed oil for the purpose of biodiesel production," Energy and Fuels, vol. 22, no. 1, January 2008. [Online]. Available: https://doi.org/10.1021/ef070105o

[32] M. Galván, J. Hernández, L. Baños, J. Noriega, and M. E. Rodríguez, "Characterization of calcium carbonate, calcium oxide, and calcium hydroxide as starting point to the improvement of lime for their use in construction," J. Mater. Civ. Eng., vol. 21, no. 11, pp. 625-708, Nov. 2009.

[33] M. I. Zaki, H. Knözinger, B. Tesche, and G. A. H. Mekhemera, "Influence of phosphonation and phosphation on surface acid-base and morphological properties of $\mathrm{CaO}$ as investigated by in situ FTIR spectroscopy and electron microscopy," J. Colloid Interface Sci., vol. 303, no. 1, November 1 2016. [Online]. Available: https://doi.org/10.1016/j.jcis.2006.07.011

[34] S. Kaewdaeng, P. Sintuya, and R. Nirunsin, "Biodiesel production using calcium oxide from river snail shell ash as catalyst," Energy Procedia, vol. 138, October 2017. [Online]. Available: https: //doi.org/10.1016/j.egypro.2017.10.057

[35] R. S. Putra and et al, "Enhanced Electro-Catalytic Process on the Synthesis of FAME Using CaO from Eggshell," Energy Procedia, vol. 105, May 2017. [Online]. Available: https://doi.org/10.1016/j.egypro. 2017.03.316

[36] A. Abad, M. Arno, L. R. Domingo, and R. J. Zaragoza, "Synthesis of (+)-podocarp-8(14)-en-13-one and methyl-(+)-13-oxo-podocarp-8(14)-en-18-oate from abietic acid," Tetrahedron, vol. 41, no. 21, 1985. [Online]. Available: https: //doi.org/10.1016/S0040-4020(01)96734-1 